\title{
Perception of the Quality of Educational System for Entrepreneurship - Comparative Analysis
}

\section{Beata Gavurova ${ }^{1}$, Jaroslav Belas ${ }^{1}$, Martin Cepel $^{2}$, Iveta Kmecova ${ }^{3}$}

${ }^{1}$ Tomas Bata University in Zlín, Faculty of Management and Economics, Zlín, Czech Republic; gavurova@utb.cz; belas@utb.cz

${ }^{2}$ Paneuropean University in Bratislava, Faculty of Economics and Business, Slovakia; martin.cepel@paneurouni.com

${ }^{3}$ Institute of Technology and Business, Faculty of Corporate Strategy, České Budějovice, Czech Republic; kmecova@mail.vstecb.cz

Abstract: High-quality entrepreneurial education has a positive influence on SMEs' development, the establishment of start-ups, business innovation, and many macroeconomic indicators. The aim of this study is to examine and evaluate the quality of the educational system from the standpoint of SME owners and managers. The analysis is aimed at detecting connections between respective respondent categories based on their region, type of business, industry, length of business operation, attained employees' education, and gender. The comparative analysis aims at examining the differences between Czech and Slovak SME entrepreneurs' perceptions of the educational system quality. The research results prove that selected differential viewpoints enable us to see the differences in how the quality of high school and university education is perceived, partially due to managers' diverse demands as to the workforce in their respective enterprises, its integration into the work process, and the job position. This micro-view is complemented by a macro-view - demands and requirements regarding the workforce are differentiated also by the size of the enterprise, its type, length of operation, etc. in both countries. The results provide valuable information for the authors of economic and educational policies, as well as for regional strategic development planning. They also emphasize the importance of a systematic approach in solving the issue of entrepreneurial education and the need to ensure support for enterprises on all levels of education, including lifelong learning.

Keywords: SME; entrepreneurial education; key competences; quality of education; college education; educational policies; competitiveness of educational systems 


\section{Introduction}

The topic of entrepreneurial education in state educational systems is the topic of many professional and scientific discussions and represents a large part of international legislative and legal platforms. Entrepreneurial education and the development of entrepreneurial skills are parts of the curriculum in primary and secondary schools in the Czech Republic and Slovakia. Primary schools, as opposed to secondary schools, do not have a complex program of entrepreneurial education in place. There is also a substantial difference between entrepreneurial education in secondary schools; however, it is included in the school curriculums of all study fields. The situation is different in university education where the greatest emphasis is put on gaining specific professional and key competences with the aim of producing a qualified workforce for the labour market. Entrepreneurial education in university environment is therefore viewed by Slovak experts as insufficient compared to tendencies that are predominant in many other countries [1].

Entrepreneurial education in Slovakia is defined as a mere cross-section field on the primary and secondary school level. Entrepreneurial skills are incorporated into secondary school curriculums as mandatory key competences in Social Studies classes. Many public and private organizations play an important role in this process (e.g. Slovak Centre for Training Firms, Junior Achievement Slovakia, Entrepreneurs Association of Slovakia, and Pontis Foundation), projects and initiatives aimed at entrepreneurial education and skills development [1]). Slovakia also participates in European projects such as The Entrepreneurial School (TES) [2], The European Entrepreneurship Education Network (EE HUB), Athéna++: The vision of the primary and secondary educational system in the $21^{\text {st }}$ Century [3].

The Czech Republic supports entrepreneurial education through various programmes, e.g. National programme for education development in the Czech Republic, The Czech Republic strategy on educational policy till 2020, The Youth Support Framework of the Czech Republic 2014 - 2020, etc. The topic of entrepreneurial education remains inferior within these programs [4].

Entrepreneurial education nowadays belongs to the main stimuli of entrepreneurial development in the European countries and its significance is acknowledged not only in primary schools, high schools, and universities but also in lifelong education. This is confirmed by the strategic document "Europe 2020" in which the priorities of intellectual growth and inclusive growth combined with innovation, knowledge, economic support, and high employment rate are connected with education-related initiatives.

These consequent facts served as amotive for performing this research. Its aim is to examine and evaluate the quality of the educational system in the Czech Republic and Slovakia as viewed by SME entrepreneurs in both countries. They 
expressed their views regarding the quality of a university and high school education in their respective countries, the state's ability to provide a workforce for businesses, and graduates' level of knowledge and skills.

The originality of this research lies in the evaluation of active feedback, i.e., students' readiness for real jobs in businesses as seen by the employers, as opposed to other available studies based more on the explicit research of entrepreneurial competences and skills in the process of education as seen by schools and graduates. It is the very employers who are best able to assess the quality of the workforce in their own business conditions and evaluate its effectiveness through the metrics of productivity, innovation development, flexibility, loyalty, etc. The research conducted by employers provide a valuable source of information about the differences between graduates' expected and actual key competences in real life. These show if and to what extent key entrepreneurial competences are incorporated into curriculums as explicit educational goals or as a merely intuitive, integral part of education.

\section{Overview of National and International Research Studies}

A number of research studies on entrepreneurial education often present the issue of achieving and developing key entrepreneurial competences. Their significance is dominant in the studies of e.g., Barbara Hansen Čechová [5], Suchožová [6], and others. National and European documents feature them in a more implicit way (e.g. [7], [8]). Key competences are also a subject of international research such as AHELO, PIAAC, and PISA [9], [10]. Many concepts examined within these studies serve also as a platform for comparative studies conducted in various countries [11], [12].

As seen in available national and international research studies, there is an obvious tendency to examine the topic of entrepreneurial education in two research lines: psycho-social and economic. They are interconnected and create a platform for examining heterogeneous aspects of entrepreneurial education. This is related to a basic dichotomy that exists between the evaluation of actual knowledge and the evaluation of competences. The dichotomy stems from differential standpoints. In his study, Gordon [13] presents interesting differential viewpoints, evaluating key competences on four levels: explicit evaluation, implicit evaluation, evaluation of competences pertaining to a school subject, and knowledge evaluation. There is an international trend of substituting the evaluation of factual knowledge with the evaluation of competences. In Slovakia, however, according to a study by Vančo et al. [14], there is a prevalence of the evaluation of competences related to school subjects and evaluation of knowledge. 
From the economic point of view, it is important within entrepreneurial education to also examine financial literacy and financial self-confidence which may affect the attitude towards risk and consequently also financial decision-making [15], [16]. This has led to the increase in the number of research studies examining entrepreneurial education in connection with student financial literacy at all educational levels in the last two decades. It is a consequent fact, as students' inadequate financial literacy can have a highly negative economic and social impact in both the short and long-term. Examples of negative macroeconomic effects include an increase in debt due to short-term and long-term loans from commercial banks (e.g. [17]), increase in risky financial decisions (e.g. [18], [19]), deepening of the financial crisis, overall negative impact on socio-economic results due to intellectual potential decrease ([20]), etc. As a part of the legislative and legal field, the existence of national standards serves as evidence of a close connection between entrepreneurial education and financial literacy. Many countries are actively working on regulating financial literacy while measuring the impact on many economic dimensions. This can be proven by a number of international research studies aimed at the assessment of procedural and result trajectories of financial literacy regulation in specific countries (e.g. [21]) as well as by a variety of research with evidence of the importance of prerequisites of entrepreneurial intensions forming by means of university education, vocational training financed by enterprises [22]). The aspirations of young adults in entrepreneurial activities can be influenced by numerous social factors, however, an educational background remains one of the most significant ([23], [24]).

The quality of state educational systems can also be examined using the outcomes of international surveys such as Global Entrepreneurship Monitor (GEM) and Global Entrepreneurship Development Index (GEDI) [25]. In Slovakia, the Ministry of Education, Science, Research and Sport of the Slovak Republic studies the following key competences: digital, social, civil as well as initiative, and entrepreneurial skills [14]. As seen in findings of institutional research conducted in Slovakia, the significant limitation in studying key competences by universities is caused by the incorrect perception of their meaning, which leads to substantial misinterpretation of the results and limits the national and international comparative platform. Johnes et al. [26] generalize this problem by bringing it to an international level while pointing to problems in individual countries - analysis issues across countries and their significance for the referential evaluation of educational policies, the need to understand the impact of financial policies on the quality, effectiveness, fairness of education, and the need to analyse educational activities in a dynamic environment, etc. The authors state that feedback from students is also important in analysing the effectiveness of tertiary education and understanding the methodological processes, using various models of education effectiveness, alternative evaluation models, etc. 


\section{Aim, Data Base and Methodology}

The aim of this study is to examine and evaluate the quality of the educational system as viewed by SME owners and managers. The analysis is aimed at detecting connections between respective respondent categories based on their region, type of business, industry, length of operating a business, attained education, and gender. The main topic of interest was the extent of similarities and differences in both Czech and Slovak SME owners' and managers' views on the quality of the educational system and graduates' readiness for real jobs.

In regard to the defined aim, survey-based research was conducted with enterprises operating in the SME segment in the Czech Republic and Slovakia in 2018. They were randomly selected from the "Albertina" and "Cribis" databases and approached via email asking them to fill in an online questionnaire. The questionnaire was intended for business owners or members of the top management. A total of 9400 SMEs were approached. 312 usable questionnaires were obtained in the Czech Republic and 329 in Slovakia. Factors indicating/reflecting/expressing the quality of the educational systems in the Czech Republic and Slovakia were examined using four questions defined and analysed in the following analytical section.

Crosstables were used to analyse the ratios of examined variables. They serve as a conventional tool for testing the relationship between two categorical or qualitative variables. The crosstables test the mutual correlation between pairs of attributes. The test compares the actual absolute numbers in individual fields with so-called expected absolute numbers that would be obtained if the questions did not correlate. The null hypothesis is as follows: the two given attributes have no correlation. Alternative hypothesis: the two given attributes correlate. If value $\mathrm{p}$ is larger than 0.05 , then the null hypothesis claiming no correlation between the two attributes is accepted. If the value of $\mathrm{p}$ is smaller than 0.05 , then the null hypothesis is rejected, meaning that the two given attributes correlate. The critical value of $p$ was set at $p=0.001$. Rejecting the null hypothesis does not express the type of correlation of the cause of the test's significance. The following variables will be used for testing the significance level of the two attributes' correlation. The actual count in row $i$ and column $j$ of the table is marked by a symbol.

If the sum in column $\mathrm{j}$ is:

$$
c_{j}=\sum_{i=1}^{R} f_{i j} .
$$

and the sum in row $\mathrm{i}$ is:

$$
r_{i}=\sum_{j=1}^{c} f_{i j}
$$


Then the total sum of the table is:

$$
N=\sum_{i=1}^{R} r_{i}=\sum_{j=1}^{C} c_{j} \text {. }
$$

The expected count therefore is:

$$
E_{i j}=\frac{r_{i} c_{j}}{N}
$$

Variable "Adjusted Residual" to be used is defined by:

$$
A R_{i j}=\frac{R_{i j}}{\sqrt{E_{i j}\left(1-\frac{r_{i}}{N}\right)\left(1-\frac{c_{j}}{N}\right)}} .
$$

The crosstable contains the abbreviation "AR" for "Adjusted Residual" in the absolute Count field. It is a variable indicating the deviation between the actual and the expected counts, as well as its direction [32]. If the AR value is negative, the real count is smaller than expected. If the value is positive, then the actual count is larger than expected (the number in the given field is larger than it should be). The numerical symbol indicates the deviation direction. Absolute value AR indicates the significance of the difference between the actual and the expected count. If $|\mathrm{AR}|$ is larger than 2 , then the difference between the actual and the expected count is significant at the level of $\mathrm{p}<0.05$. If the value is larger than 2.6, then the difference between the actual and the expected count is significant at the level of $\mathrm{p}<0.01$. Given a large number of tests and a large count, the significant difference between the actual and the expected count is set at $|\mathrm{AR}|>3.3$ in the given field. If the value is larger than 3.3, then the difference between the actual and the expected count has a significance level of $\mathrm{p}<0.001$.

Within the analysis, the following regions were observed at level 3 of the Nomenclature of Territorial Units for Statistics: CZ010 - Prague Region; CZ020 Centre Czechia Region; CZ031 - South Czechia Region; CZ032 - Plzeň Region; CZ041 - Karlovy Vary Region; CZ042 - Ústí Region; CZ051 - Liberec Region; CZ052 - Hradec Králové Region; CZ053 - Pardubice Region; CZ063 -Vysočina Region; CZ064 - South Moravia Region; CZ071 - Olomouc Region; CZ072 Zlín Region; CZ080 - Moravia-Silesia Region; SK010 - Bratislava Region; SK021 - Trnava Region; SK022 - Trenčín Region; SK023 - Nitra Region; SK031 - Žilina Region; SK032 - Banská Bystrica Region; SK041 - Prešov Region; and SK042 - Košice Region. 


\section{Analysis and Results}

The analytical part of the study is divided into four sections (a-d), each one dealing with a separately verified claim made by the respondents. The first part (a) offers an analysis of the respondent's position on the claim that university education can be viewed as that of high quality. The second part (b) deals with a similar statement, but pertains to secondary education; the third part (c) refers to the claim that the state is able to provide a qualified workforce for businesses, and the last part (d) examines the claim that graduates have high quality knowledge and skills.

\subsection{See University Education as that of a High Quality}

The claim that university education is that of high quality can be evaluated based on region, type of business, industry, and attained education. The length of operating a business and gender parameters do not show a statistical significance in either of the studied categories. In terms of region, the Trnava Region in the Slovak Republic, there is a considerably high residual of negative answers, which means that the actual number of neutral answers is lower than expected. The business type aspect is significant in the case of absolute negative answers by respondents from medium-sized enterprises (having more than 50 employees) where the residual reaches an extremely high positive value which means that there are many more answers from the Czech Republic than expected. The industry aspect is statistically significant in the manufacturing field whose respondents absolutely disagreed with the claim that university education is of high quality. There were fewer answers in the Czech Republic than expected. In Slovakia, the "agriculture" sector was statistically significant, as the number of answers was considerably lower than expected, but unlike in the Czech Republic, this is valid for the absolute positive standpoint. Education was the last category examined. In the Czech Republic, the respondents with secondary education expressed disagreement at a much higher rate than expected. A similar result was achieved in the case of respondents with a university diploma. However, they provided a much higher number of positive responses to the question about the quality of university education, which is a paradox, given the fact that the evaluation was done by managers with secondary education.

\subsubsection{Comparison between Countries}

Table 1 presents the statistical significance of answers to the question of whether a university education is that of a higher quality, based on country. 
Table 1

Crosstab of answers to: "I see university education as that of a higher quality", based on country

\begin{tabular}{|c|c|c|c|c|c|}
\hline \multicolumn{3}{|l|}{ Attribute } & $\mathrm{CZ}$ & SK & Total \\
\hline \multirow[t]{10}{*}{ Answers } & \multirow[t]{2}{*}{ I absolutely disagree } & count & $14_{a}$ & $14 \mathrm{a}$ & 28 \\
\hline & & $\%$ & 4.5 & 4.3 & 4.4 \\
\hline & \multirow[t]{2}{*}{ I disagree } & count & $62 \mathrm{a}$ & 133 b & 195 \\
\hline & & $\%$ & 19.9 & 40.4 & 30.4 \\
\hline & \multirow[t]{2}{*}{ Neutral } & count & $107 \mathrm{a}$ & $66 \mathrm{~b}$ & 173 \\
\hline & & $\%$ & 34.3 & 20.1 & 27.0 \\
\hline & \multirow[t]{2}{*}{ I agree } & count & $119 \mathrm{a}$ & $107 \mathrm{a}$ & 226 \\
\hline & & $\%$ & 38.1 & 32.5 & 35.3 \\
\hline & \multirow[t]{2}{*}{ I absolutely agree } & count & $10_{\mathrm{a}}$ & $9 \mathrm{a}$ & 19 \\
\hline & & $\%$ & 3.2 & 2.7 & 3.0 \\
\hline \multirow{2}{*}{\multicolumn{2}{|c|}{ Total }} & count & 312 & 329 & 641 \\
\hline & & $\%$ & 100.0 & 100.0 & 100.0 \\
\hline
\end{tabular}

Source: own processing

All answers are statistically significant, while reaching the highest level of statistical significance with the exception of negative answers from respondents from Slovakia whose statistical significance is that of the second level.

\section{Comparison based on gender for the given country}

Table 2 shows the statistical significance of answers to the a question whether a university education is that of a higher quality, based on country and gender.

Table 2

Crosstab of "I see university education as that of a higher quality", based on country and gender

\begin{tabular}{|c|c|c|c|c|c|c|}
\hline \multicolumn{4}{|c|}{ Attribute } & $\mathrm{CZ}$ & SK & Total \\
\hline \multirow[t]{12}{*}{ Male } & \multirow[t]{10}{*}{ Answers } & \multirow{2}{*}{$\begin{array}{l}\text { I absolutely } \\
\text { disagree }\end{array}$} & count & $11_{\mathrm{a}}$ & $13 \mathrm{a}$ & 24 \\
\hline & & & $\%$ & 4.7 & 5.2 & 4.9 \\
\hline & & \multirow[t]{2}{*}{ I disagree } & count & $52 \mathrm{a}$ & $99_{\mathrm{b}}$ & 151 \\
\hline & & & $\%$ & 22.0 & 39.4 & 31.0 \\
\hline & & \multirow[t]{2}{*}{ Neutral } & count & $82 \mathrm{a}$ & $55_{b}$ & 137 \\
\hline & & & $\%$ & 34.7 & 21.9 & 28.1 \\
\hline & & \multirow[t]{2}{*}{ I agree } & count & $83 \mathrm{a}$ & $78 \mathrm{a}$ & 161 \\
\hline & & & $\%$ & 35.2 & 31.1 & 33.1 \\
\hline & & \multirow[t]{2}{*}{ I absolutely agree } & count & $8 \mathrm{a}$ & $6 a$ & 14 \\
\hline & & & $\%$ & 3.4 & 2.4 & 2.9 \\
\hline & \multirow{2}{*}{\multicolumn{2}{|c|}{ Total }} & count & 236 & 251 & 487 \\
\hline & & & $\%$ & 100.0 & 100.0 & 100.0 \\
\hline \multirow[t]{2}{*}{ Female } & \multirow[t]{2}{*}{ Answers } & \multirow{2}{*}{$\begin{array}{l}\text { I absolutely } \\
\text { disagree }\end{array}$} & count & $3 \mathrm{a}$ & 1a & 4 \\
\hline & & & $\%$ & 3.9 & 1.3 & 2.6 \\
\hline
\end{tabular}




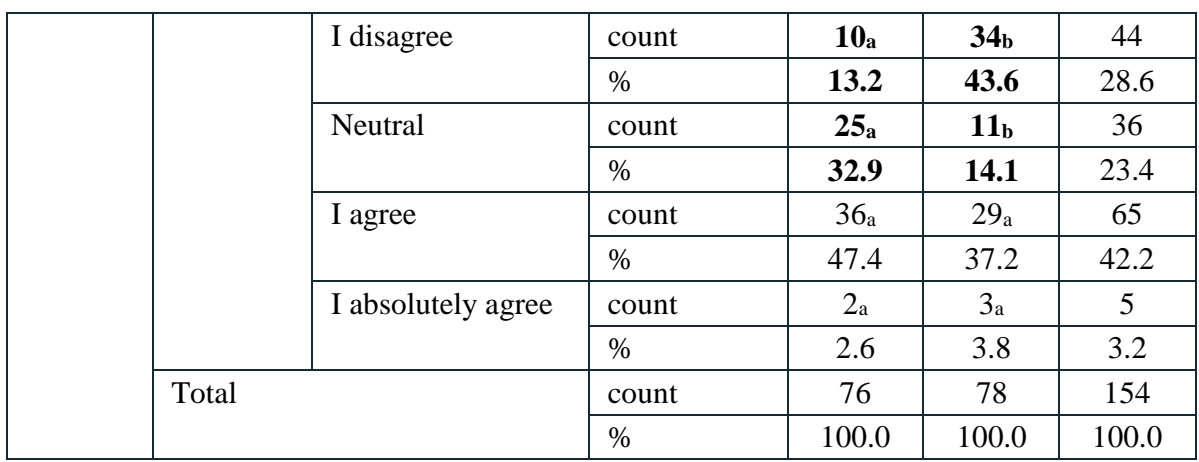

Legend: statistical significance: $\mathrm{a}-1$ st level, $\mathrm{p}<0.01 ; \mathrm{b}-2 \mathrm{nd}$ level, $\mathrm{p}<0.05$

Source: Own processing

All answers are statistically significant; the second level of statistical significance is reached in negative and neutral answers obtained from male respondents in Slovakia, and the same categories of female respondents in Slovakia. All other options can be assigned the highest level of statistical significance.

\section{Comparison based on education}

Table 3

Crosstab. of: "I see university education as that of a high quality", based on attained education level

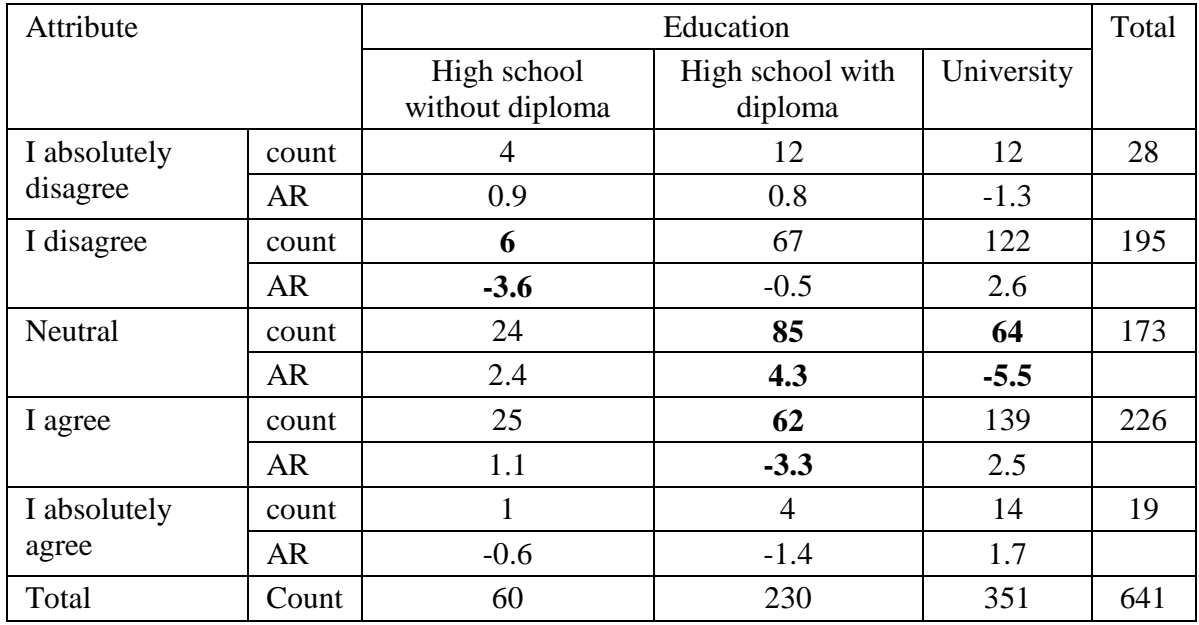

Source: Own processing

The values of adjusted residuals reach statistically significant levels in negative answers of the respondents with secondary education without a diploma, as the negative residual value presents a higher number of answers than expected, given the source file. In the case of neutral answers, a statistically significant residual value was reached in the answers from the respondents with secondary education, where the maximum positive value of 4.3 represents a much lower number of 
answers in this group than expected. The same goes for the opposite critical value in the case of the negative residual value reaching an even higher absolute level of 5.5 which means that there was a much higher number of answers than expected, given the source file. There is also a statistically significant value in the answers of the respondents with a secondary education with a diploma, where the residual value is negative, meaning that an unexpected number of the respondents in this category agreed with the statement that university education can be seen as that of high quality.

\section{Comparison based on education for the given country}

Table 4

Crosstab of: "I see university education as that of a higher quality ", based on attained education

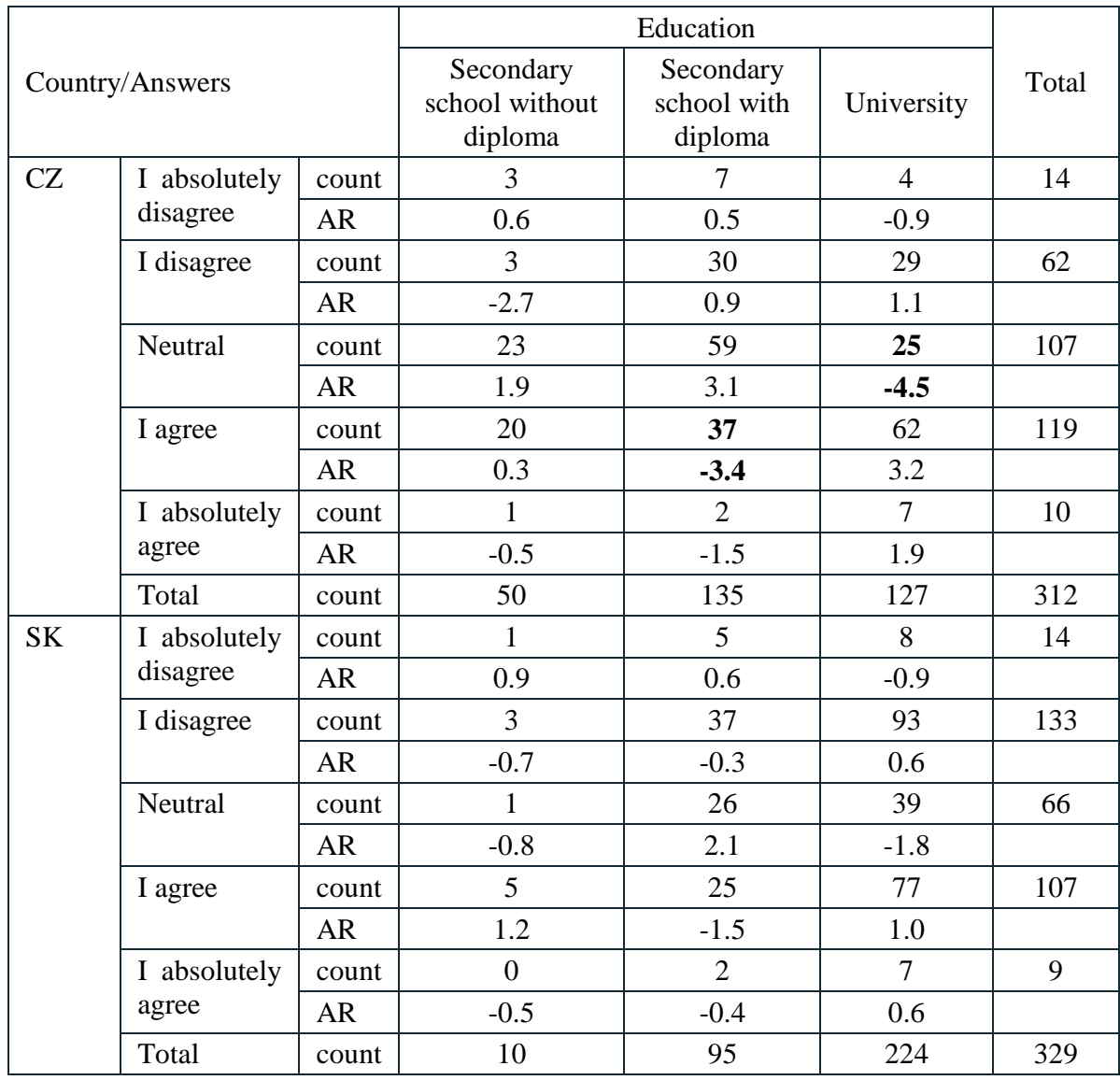

Source: Own processing

As for education, there were two cases in the Czech Republic when the residuals reached statistically significant values. The first one was a case of the neutral 
position of university-educated respondents with a negative residual, indicating an unexpectedly high number of people in this category having a neutral opinion of the quality of university education. The second was a case of positive standpoint towards the same claim, with a large number of answers from respondents with secondary education with a diploma. Slovak respondents, on the opposite, responded as expected; therefore, the residuals did not reach statistically significant values. Comparing the two countries, it is apparent that in the case of Slovak respondents, none of the categories is statistically significant, which means that the comparison between countries is not possible in this case.

\subsection{See Secondary Education as that of a High Quality}

The length of business operation and gender parameters do not show a statistical significance in either of the studied categories. In terms of region, there are three cases of statistically significant residuals due to their positive values in the Czech Republic: the Hradec Králové Region with an absolute positive standpoint, the Olomouc Region with a negative standpoint, and the Zlín Region with an absolute negative standpoint. Unlike in the Czech Republic, in Slovakia, there is a case of negative residual value, namely in the Prešov Region, which had a considerably higher number of absolute positive answers than expected. At the same time, the same region also yielded positive statistically significant residuals in the case of a neutral standpoint with a lower number of answers than expected. The business type aspect is statistically significant in both countries. In the Czech Republic, there are two cases of positive residuals - in the "other industry" with a lower number of neutral answers than expected, and in the case of "manufacturing". Positive residuals are also found in Slovakia, but in different cases - in "services" and "other industry". As for the respondents' attained education aspect, a statistically significant residual value is present in the group of the respondents with a secondary education without a diploma who showed a higher than expected response rate to the claim that secondary education is of a higher quality by providing an absolute negative answer.

\subsection{The State is Able to Provide a Qualified Workforce for Businesses}

The education and gender aspects do not show a statistical significance in either of the studied categories. In terms of region, there are two cases of high positive residuals in the Czech Republic indicating that the respondents from the Central Bohemian Region and the Karlovy Vary Region absolutely disagree with the claim above to a much lesser degree than expected. In the Prešov Region in the Slovak Republic, the situation was similar as in the above-mentioned Czech regions, while the Bratislava Region and the Trnava Region yielded negative residuals indicating a considerably higher rate of negative answers than expected. 
The business type aspect is statistically significant in the case of a negative and an absolute negative answer of the respondents from small enterprises with $10-50$ employees in the Czech Republic, where a lower number of answers was observed than expected. This is the only situation of statistically significant residuals in two respondent standpoints within the same question. The situation is more diversified in Slovakia, as there is a considerably lower number of negative answers from small enterprises having 10 - 50 employees, but a much higher number of negative answers from micro-enterprises having up to 10 employees. Medium-sized enterprises having more than 50 employees yielded a considerably higher number of neutral answers than expected. The industry aspect is statistically significant in the Czech Republic in the "agriculture" sector which shows extremely high positive residuals. This means that the number of absolute negative answers is extremely low. In Slovakia, the "other industry" sector shows a low number of absolute negative answers. In the Czech Republic, the length of business operation aspect yielded a statistically significant positive residual in the case of absolute negative answers, which means that the respondents provided a much lower number of absolute negative answers than expected.

\section{Comparison based on the size of business}

Conclusion: the respondents from small enterprises (up to 10 employees) are less satisfied with their employees' education level than the respondents from medium-sized enterprises (10 - 50 employees).

Table 5

Crosstab of "The state is able to provide a qualified workforce for businesses", based on business size

\begin{tabular}{|c|c|c|c|c|c|}
\hline \multicolumn{2}{|l|}{ Answers } & \multicolumn{3}{|c|}{ Size of enterprise (number of employees) } & \multirow{3}{*}{$\begin{array}{c}\text { Total } \\
99\end{array}$} \\
\hline & & up to 10 & $10-50$ & $50-250$ & \\
\hline \multirow{2}{*}{$\begin{array}{l}\text { I absolutely } \\
\text { disagree }\end{array}$} & count & 75 & 19 & 5 & \\
\hline & AR & -0.3 & 0.4 & -0.2 & \\
\hline \multirow[t]{2}{*}{ I disagree } & count & 256 & 44 & 20 & 320 \\
\hline & AR & 1.9 & -2.7 & 0.9 & \\
\hline \multirow[t]{2}{*}{ Neutral } & count & 117 & 15 & 2 & 134 \\
\hline & AR & 3.3 & -2.2 & -2.3 & \\
\hline \multirow[t]{2}{*}{ I agree } & count & 42 & 34 & 8 & 84 \\
\hline & AR & -6.2 & 5.8 & 1.8 & \\
\hline \multirow{2}{*}{$\begin{array}{l}\text { I absolutely } \\
\text { agree }\end{array}$} & count & 2 & 2 & 0 & 4 \\
\hline & $\mathrm{AR}$ & -1.3 & 1.7 & -0.5 & \\
\hline Total & count & 492 & 114 & 35 & 641 \\
\hline
\end{tabular}

Source: Own processing

As shown in Table 5, a comparison based on the business size yields three cases of statistically significant residuals. The neutral standpoint of respondents can be validated due to a positive residual in the case of small enterprises having up to 10 
employees. A higher number of answers was expected in this case. Another statistically significant case comes from the same business size group in which the residual reached an extremely low value of -6.2 , indicating an unexpectedly high number of people agreeing with the claim that the state is able to provide a qualified workforce for businesses. At the same time, there was also an extreme case of a positive standpoint in an enterprise of $10-50$ employees where the number of answers was considerably lower than expected.

\section{Comparison based on size of the business for the given country}

Conclusion: Slovak entrepreneurs from small enterprises show a lower degree of trust towards the state in providing qualified workforce for businesses, as opposed to medium-sized enterprises.

Table 6

Crosstab of "The state is able to provide a qualified workforce for businesses ", based on business size

\begin{tabular}{|c|c|c|c|c|c|c|}
\hline & \multicolumn{4}{|c|}{ Size of enterprise (number of employees) } \\
\hline & & & up to 10 & $10-50$ & $50-250$ & Total \\
\hline \multirow{11}{*}{$\mathrm{CZ}$} & \multirow{2}{*}{ I absolutely disagree } & count & 40 & 9 & 1 & 50 \\
\hline & & $\mathrm{AR}$ & -0.5 & 0.9 & -0.6 & \\
\hline & \multirow{2}{*}{ I disagree } & count & 131 & 16 & 7 & 154 \\
\hline & & AR & 1.1 & -1.7 & 1.0 & \\
\hline & \multirow{2}{*}{ Neutral } & count & 68 & 7 & 2 & 77 \\
\hline & & $\mathrm{AR}$ & 1.5 & -1.4 & -0.5 & \\
\hline & \multirow{2}{*}{ I agree } & count & 19 & 10 & 1 & 30 \\
\hline & & AR & -2.9 & 3.3 & -0.1 & \\
\hline & \multirow{2}{*}{ Absolutely agree } & count & 0 & 1 & 0 & 1 \\
\hline & & $\mathrm{AR}$ & -2.2 & 2.5 & -0.2 & \\
\hline & Total & count & 258 & 43 & 11 & 312 \\
\hline \multirow{11}{*}{ SK } & \multirow{2}{*}{ I absolutely disagree } & count & 35 & 10 & 4 & 49 \\
\hline & & AR & 0.1 & -0.2 & 0.3 & \\
\hline & \multirow{2}{*}{ I disagree } & count & 125 & 28 & 13 & 166 \\
\hline & & $\mathrm{AR}$ & 1.7 & -2.1 & 0.4 & \\
\hline & \multirow{2}{*}{ Neutral } & count & 49 & 8 & 0 & 57 \\
\hline & & AR & 2.7 & -1.5 & -2.3 & \\
\hline & \multirow{2}{*}{ I agree } & count & 23 & 24 & 7 & 54 \\
\hline & & AR & -5.1 & 4.5 & 1.8 & \\
\hline & \multirow{2}{*}{ I absolutely agree } & count & 2 & 1 & 0 & 3 \\
\hline & & AR & -0.2 & 0.5 & -0.5 & \\
\hline & Total & count & 234 & 71 & 24 & 329 \\
\hline
\end{tabular}

Source: Own processing 
The values of adjusted residuals reach statistically significant levels in positive answers of the respondents from enterprises of up to 10 employees or $10-50$ employees. This is only valid for Slovakia. In the case of respondents from small enterprises having up to 10 employees, there was a case of negative residual indicating a considerably higher number of answers than expected. In mediumsized enterprises with 10-50 employees, a lower number of answers was obtained than expected. Unlike in Slovakia, there was a borderline case in the Czech Republic of statistically significant residual values in neutral answers in small enterprises having 10-50 employees.

\subsection{Graduates have High-Quality Knowledge and Skills}

The education and gender parameters do not show a statistical significance in either of the studied categories. Considering the region aspect, there is a considerably negative residual in the Bratislava Region of the Slovak Republic, meaning that the actual number of answers expressing an absolute positive standpoint towards the above claim is higher than expected. There was an opposite case in the Prešov Region, in which a high positive residual was observed in a case of negative answers in, indicating a considerably higher number of negative responses than expected. Considering the business type aspect, a statistically significant residual was observed in the Czech Republic where the respondents from medium-sized enterprises with more than 50 employees showed a considerably lower response rate in case of an absolute negative standpoint. The industry aspect is statistically significant in the Slovak "services" sector which yielded a much lower response rate than expected in case of an absolute positive standpoint.

Table 7

Evaluation of questions in the field of education in the Czech Republic and Slovakia

\begin{tabular}{|l|r|r|r|}
\hline Question & $\begin{array}{l}\text { Ratio of positive } \\
\text { answers (in \%) in } \\
\text { Czech Republic }\end{array}$ & $\begin{array}{l}\text { Ratio of positive } \\
\text { answers (in \%) in } \\
\text { Slovakia }\end{array}$ & $\begin{array}{l}\text { Z-score p- } \\
\text { value CR/SR }\end{array}$ \\
\hline $\begin{array}{l}\text { I see university education as } \\
\text { that of a higher quality (1) }\end{array}$ & 7.7 & 9.1 & 0.516 \\
\hline $\begin{array}{l}\text { I see secondary education as } \\
\text { that of a higher quality (2) }\end{array}$ & 30.1 & 30.7 & 0.873 \\
\hline $\begin{array}{l}\text { The state is able to provide } \\
\text { a qualified workforce for } \\
\text { businesses (3) }\end{array}$ & 11.2 & 15.5 & 0.112 \\
\hline $\begin{array}{l}\text { Graduates have high quality } \\
\text { knowledge and skills (4) }\end{array}$ & 10.6 & 16.1 & 040 \\
\hline
\end{tabular}

Source: own processing

The overview of positive answers shows a considerable disproportion between the respondents in both countries and confirms the fact that the higher rate of neutral 
answers decreases the rate of positive answers. Only question 4 yields statistically significant answers, as the p-value of the Z-score statistical method is lower than the $5 \%$ significance level. Even though the p-value is higher in question 3 , this question can be evaluated as well, but at a higher significance level than it reaches. It barely exceeds the standard $10 \%$ significance level. There was a prevalence of positive answers in all four questions in Slovakia.

Table 8

Average values of answers based on the Likert scale in respective regions

\begin{tabular}{|c|c|c|c|c|}
\hline Region & Question (1) & Question (2) & Question (3) & Question (4) \\
\hline CZ010 & 2.118 & 2.471 & 2.353 & 2.235 \\
\hline CZ020 & 2.286 & 2.5 & 3 & 2.714 \\
\hline CZ031 & 2.313 & 2.125 & 2.188 & 2.375 \\
\hline CZ032 & 1.955 & 2.045 & 1.955 & 2.136 \\
\hline CZ041 & 2.4 & 2.533 & 2.467 & 2.467 \\
\hline CZ042 & 1.667 & 2.074 & 2.259 & 2.185 \\
\hline CZ051 & 2.714 & 2.75 & 2.536 & 2.5 \\
\hline CZ052 & 2 & 2.353 & 2.824 & 2.765 \\
\hline CZ053 & 2 & 2.353 & 2.294 & 2.412 \\
\hline CZ063 & 2 & 2.16 & 1.88 & 1.88 \\
\hline CZ064 & 2.045 & 2.818 & 2.227 & 2.455 \\
\hline CZ071 & 2.731 & 2.769 & 2.769 & 2.654 \\
\hline CZ072 & 2.265 & 2.673 & 2.51 & 2.51 \\
\hline CZ080 & 2.353 & 2.235 & 2.353 & 2.353 \\
\hline SK010 & 2.036 & 2.179 & 1.839 & 2.393 \\
\hline SK021 & 2.333 & 2.222 & 1.889 & 2.63 \\
\hline SK022 & 2.1 & 1.85 & 1.9 & 2.3 \\
\hline SK023 & 1.765 & 1.941 & 1.765 & 2.118 \\
\hline SK031 & 1.607 & 1.679 & 1.393 & 1.75 \\
\hline SK032 & 2.267 & 2.133 & 1.967 & 2.467 \\
\hline SK041 & 2.553 & 3.053 & 2.658 & 3 \\
\hline SK042 & 2.68 & 2.493 & 2.627 & 2.88 \\
\hline
\end{tabular}

Source: Own processing 
Table 8 showing average values of answers based on the Likert scale in respective regions confirm a relative neutral standpoint in the case of the respondents from the Czech Republic. Slovak respondents avoided the neutral answer at a significant level. The lowest value was observed at 1.88 in the Vysočina Region in questions (3) and (4). Value 1.88 indicates the average position between an absolute negative answer and a negative answer. The maximum value of 3 was observed in the Central Bohemian Region in question (3), which indicates a neutral answer. In the case of extreme values, there is a larger variance of answers of the respondents in Slovakia than those in the Czech Republic. The minimum value of 1.607 is valid for the Žilina Region in question (1), while the maximum value of 3 was reached in the Prešov Region in question (4). The variance of average values based on the Likert scale is approximately twice as low.

\section{Discussion}

In the last decade, EU countries really strive to ensure the implementation of „entrepreneurial skills“ as a key competence into their school curriculum's within primary, secondary, specialized, and higher education [1]. Turek [28] states that acquiring key competences is not merely the responsibility of an individual; favourable conditions within a social and ecological environment must exist as well. Based on the materials from the European Commission [7], it is necessary to encourage the development of $21^{\text {st }}$ Century skills and prepare individuals for a career that can be very diversified and unpredictable. Young people should learn entrepreneurial behaviour to be able to adapt to dynamic changes on the labour market that they will encounter in their professional life [29].

Key competences are often monitored and evaluated mainly from the psychosocial point of view, which explains the difficulties in their quantification. Their connection with economic and social systems can only be seen in the past years through examining individual personalities and their success rate parameters, as well as leadership roles and psychological aspects of entrepreneurship. From the economic point of view, key competences positively have a positive impact on productivity growth and work effectivity, competitiveness, flexibility and workforce adaptation, the creation of an innovative and creative environment, etc. Business managers explicitly relate business effectivity to job performance, and monitor employees' job positions based on personal characteristics, attained education, experience, skills, and key competences [30]. These characteristics are usually examined and evaluated by managers as a whole, as systems for measuring performance are designed to define quantifiable parameters [31]. Human resources in businesses are the most sensitive performance parameter due to their high perception of economic success as well as risks and losses. 
These consequent facts justify the importance of a wide array of workforce researches in order to receive the best possible real-life feedback. There is a limited number of workforce researches due to their methodological difficulty, complexity, and low return on research materials, institutional support is, therefore, very important. If provided, it can support the creation of national and international benchmarks in this field. Their very absence causes strong heterogeneity in research processes that monitor the quality of education and the comparative limitations on both national and international scale.

The research results prove that selected differential viewpoints enable us to see the differences in how the quality of high school and university education is perceived, partially due to managers' diverse demands as to the workforce in their respective enterprises, its integration into the work process, and the job position. This micro-view is complemented by a macro-view - demands and requirements regarding the workforce are differentiated also by the size of the enterprise, its type, length of operation, etc. in both countries. There is an obvious tendency to study managers' satisfaction with the education level of their workforce depending on the sector, the position on the market, type of enterprise, etc. Sector analyses and studies examining managers' satisfaction with their employees' education levels considering the size of the enterprise, its life cycle, etc. are gaining importance. A small business owner/manager can make a better and faster evaluation of an employee's education level and key competences, which is given by shorter and more intense communication channels, a wider spectrum of tasks, and higher demands on his/her flexibility, inventiveness, etc.

\section{Conclusion}

The aim of this study was to examine and evaluate the quality of the educational system from the standpoint of SME owners and managers in the Czech Republic and Slovakia. The analysis was aimed at detecting connections between respective respondent categories based on their region, type of business, industry, length of business operation, attained education, and gender of employees.

The claim that university education is of a higher quality was confirmed by absolute positive answers from Slovak respondents in the field of "agriculture". In the Czech Republic, significantly more positive answers on the quality of university education were obtained from the respondents with a high school diploma. In Slovakia, the neutral standpoint was statistically significant from the point of view of the Trnava Region, which means that the actual number of neutral responses was lower than expected. There was a much higher number of negative answers than expected obtained from the respondents with a university diploma in the Czech Republic. The absolute negative standpoint is statistically significant in the case of the respondents from medium-sized enterprises in the Czech Republic, where the residual reaches an extremely high positive value, which means that there was a much higher number of answers than expected. Likewise, this response was statistically significant in the "manufacturing" sector, whose 
respondents absolutely disagreed with the claim that university education is of a high quality. There were fewer responses in the Czech Republic than expected.

The claim that high school education is of a higher quality can be evaluated based on the region, type of business, industry, and the respondent's attained education. As opposed to the Czech Republic, there were cases in Slovakia, namely in the Prešov Region, of a significantly higher number of absolute positive answers than expected. Also, in the Prešov Region, a positive statistically significant residual can be found in the case of a negative standpoint, where the number of answers was lower than expected. As for the Czech Republic, the Hradec Králové Region showed an absolute positive standpoint from respondents. The "business type" aspect is statistically significant in both countries, while the respondents in the Czech Republic answered neutrally in the case of "other fields" to a lower degree than expected. The same goes for the "manufacturing" sector, as well as "services" and "other fields" in Slovakia.

The claim that the state is able to provide a qualified workforce for businesses was examined using the analysis of residuals based on region, type of business, industry, length of operating a business. Considering the region aspect, there are two cases of absolute disagreement of a much lesser degree than expected - in the Centre Czechia Region, the Karlovy Vary Region, and the Prešov Region. An extremely low number of negative answers were noted in the "agriculture" sector in the Czech Republic and in "other fields" in Slovakia. Absolute disagreement is statistically significant considering the "length of operating a business" aspect where a much lower number of answers was obtained than expected. A considerably higher than expected rate of negative answers was observed in the Bratislava Region and the Trnava Region. The "type of business" aspect is statistically significant in the case of a negative and absolute negative response from the respondents from small enterprises of 10-50 employees in the Czech Republic where the number of responses was lower than expected. In Slovakia, small enterprises of 10 - 50 employees yielded a considerably lower number of negative answers, while micro-enterprises with up to 10 employees provided a much higher number of negative answers.

The claim that graduates have high-quality knowledge and skills can be statistically measured based on region, type of business, industry, and length of business operation. In the Czech Republic, medium-sized enterprises having more than 50 employees yielded a much lower rate of negative answers than expected. There was an extreme case of a higher number of negative answers than expected in the Prešov Region. An absolute positive standpoint was observed at a higher rate than expected in the Bratislava Region.

Comparing the countries' aggregated evaluations, Slovak managers were more satisfied in all four research questions in terms of the quality of secondary and university education. However, it is important to permanently ensure flexibility of educational systems in both countries and make sure that they can react to 
dynamic demands on the job market. It is also necessary to improve educational policies, review them, set new goals, and implement them into strategic materials and action plans.

The analysis results provide valuable information for the authors of economic and educational policies, as well as for regional strategic development planning. They also emphasize the importance of a systematic approach in solving the issue of entrepreneurial education and the need to ensure support for enterprises at all levels of education, including lifelong learning.

\section{Acknowledgments}

The research was supported by the Research and Development Agency GA AA under the contract: No. 21/2020: "Management, business risk and the firm bankruptcy in the segment of SMEs."

\section{References}

[1] Slovak Business Agency (2019) Business Enterprise Analysis [Analýza podnikatel'ského vzdelávania] p. 74, Retrieved from: http://www.sbagency.sk/sites/default/files/analyza_podnikatelskeho_vzdela vania.pdf

[2] The Entrepreneurial School (2019) Retrieved from: https://www.tesguide.eu/

[3] Oravec, J., Pošvanc, M. et al. (2017) The Vision of the $21^{\text {st }}$ Century Primary and Secondary School Education System [Vízia systému vzdelávania študentov základných a stredných škôl v 21. storočí]. Retrieved from: http://www.hayek.sk/wpcontent/uploads/2017/02/athena_projekt_ vizia_skolstva.pdf

[4] Ministry of Education, Youth and Sport of the Czech Republic. (2020) A Strategy of Education Policy of the Czech Republic in 2020 [Strategie vzdělávací politiky České republiky do roku 2020] Retrieved from: http://www.vzdelavani2020.cz/

[5] Hansen Čechová, B. (2009) Development and Evaluation Ideas of Students' Key Competences [Nápady pro rozvoj a hodnocení klíčových kompetencí žáků] Praha: Portál, s. r. o., 2009. ISBN 978-80-7367-388-8

[6] Suchožová, E. (2013) Global Education - 21 ${ }^{\text {st }}$ Century Education. Global Education $-21^{\text {st }}$ Century Education. Methodological and Pedagogical Centre in Bratislava [Globálne vzdelávanie - vzdelávanie pre 21. storočie. Metodicko-pedagogické centrum v Bratislave] 2013, ISBN 978-80-8052474-6

[7] Európska komisia / European Commission (2019) EURÓPA 2020, A Strategy for Providing Smart Sustainable and Inclusive Growth [Stratégia na zabezpečenie inteligentného, udržatel'ného a inkluzívneho rastu] 
Retrieved from: https://eur-lex.europa.eu/legal-content/SK/ALL/ ?uri=celex\%3A52010DC2020

[8] OECD (2016) Financial Education in Europe: Trends and Recent Developments. OECD Publishing, Paris. Available at: http://dx.doi.org/10.1787/9789264254855-en

[9] Schuetze, H., Bruneau, W., Grosjean, G. (2012) University Governance and Reform: Policy, Fads, and Experience in International Perspective. Springer, p. 266

[10] OECD (2018) PISA 2018 results. Retrieved from: https://www.oecd.org/pisa/publications/pisa-2018-results.htm

[11] Vero, J. (2012) From the Lisbon Strategy to Europe 2020: The Statistical Landscape of the Education and Training Objectives Through the Lens of the Capability Approach. Social Work and Society International Online Journal, 1, 1-16

[12] Dumciuviene, D. (2015) The main aim of the article to exam the European Union education policy, its relation and impact for economic development. Procedia - Social and Behavioural Sciences, 191, pp. 2427-2436

[13] Gordon, J. et al. (2009) Key competences in Europe: Opening doors for lifelong learners across the school curriculum and teacher education, CASE Network Reports, No. 87, Retrieved from: https://www.econstor.eu/ bitstream/10419/87621/1/613705459.pdf

[14] Vančo et al. (2016) An Analysis of Obtaining Transversal Key Competences at the Slovak Universities. CVTI, 2016, 46 p. https://www.minedu.sk/data/att/10091.pdf

[15] McGraw Hill Financial. (2015) Global Financial Literacy. Retrieved September 9, 2015, Retrieved from: https://www.mhfi.com/corporateresponsibility/global-financial-literacy-survey?keyfindings

[16] Klapper, L., Lusardi, A., Oudheusden, P. (2015) Financial Literacy Around the World: Insights from the Standard \& Poor's ratings services global financial literacy survey. Retrieved December 11, 2015, Retrieved from: https://www.mhfi.com/corporate-responsibility/global-financial-literacysurvey

[17] Lusardi, A., Mitchel, O. S. (2014) The Economic Importance of Financial Literacy: Theory and Evidence (NBER Working Paper 18952). Cambridge, MA: National Bureau of Economic Research. Retrieved from: http://www.nber.org/papers/w18952

[18] Vravec, J. (2014) An Analysis of the Financial Literacy Level and Financial Situation of Eastern Slovakia Inhabitants. Derivative 4 [Analýza úrovne finančnej gramotnosti a finančnej situácie obyvatel'ov východného 
Slovenska. Derivat, 4] Retrieved from http://www.derivat.sk/ index.php?PageID=2346\&SearchString=vravec

[19] Rutledge, S., L. (2010) Consumer Protection and Financial Literacy. Lessons from Nine Country Studies (Policy Research Working Paper 5326) Washington, DC: World Bank. Retrieved October 15, 2016, Retrieved from: http://documents.worldbank.org/curated/en/676251468233092150/ Consumer-protection-and-financial-literacy-lessons-from-nine-countrystudies

[20] Bilan Y., Mishchuk, H., Roshchyk, I. \& Kmecova I. (2020) Analysis of Intellectual Potential and its Impact on the Social and Economic Development of European Countries. Journal of Competitiveness, 1, 22-38, https://doi.org/10.7441/joc.2020.01.02

[21] Kozina, F., L., Ponikvar, N. (2015) Financial Literacy of First-Year University Students: The Role of Education. International Journal of Management, Knowledge and Learning, 4(2), 241-255

[22] Çera, G., Cepel, M., Zakutna, S., \& Rozsa, Z. (2018) Gender differences in perception of the university education quality as applied to entrepreneurial intention. Journal of International Studies, 11(3), 147-160, doi:10.14254/2071-8330.2018/11-3/13

[23] Németh, E., \& Zsótér, B. (2019) Anxious spenders: Background factors of financial vulnerability. Economics and Sociology, 12(2), 147-169, doi:10.14254/2071- 789X.2019/12-2/9

[24] Kumar, N., Al Mamun, A., Ibrahim, M. D. \& Yusoff, M. N. H. (2018) Entrepreneurial orientation and antecedents of low-income household heads in Kelantan, Malaysia. Journal of International Studies, 11(1), 140-151, doi:10.14254/2071-8330.2017/11-1/10

[25] Szerb, L., Aidis, R., Acs, Z. J. (2013) The Comparison of the Global Entrepreneurship Monitor and the Global Entrepreneurship and Development Index Methodologies. Foundations and Trends® in Entrepreneurship, 9(1): 1-142, Retrieved from: http://dx.doi.org/10.1561/ 0300000046

[26] Johnes, J., Portela, M., Thanassoulis, E. (2017) Efficiency in education. Journal of the Operational Research Society, 68, pp. 331-338

[27] Everitt, B. S. (1992) The Analysis of Contingency Tables, Second Edition. CRC Press, 1992, p. 168

[28] Turek, I. (2005) Didactics Innovations. Methodological and Pedagogical Centre in Bratislava [Inovácie v didaktike. Metodicko-pedagogické centrum v Bratislave]. 2005 
[29] Bongini, P., Trivellato, P., Zenga, M. (2015) Business Students and Financial Literacy: When Will the Gender Gap Fade away? Journal of Financial Management. doi: 10.12831/80528

[30] Gavurova, B., Kubak, M., Huculova, E., Popadakova, D., Bilan, S. (2019) Financial Literacy and Rationality of Youth in Slovakia. Transformations in Business \& Economics, 18(3): 43-53

[31] Michalski, G. (2014) Value maximizing corporate current assets and cash management in relation to risk sensitivity: Polish firms' case. Economic Computation and Economic Cybernetics Studies and Research, 48(1): 259276 